\title{
Oxidative stress in preeclampsia and the role of free fetal hemoglobin
}

\author{
Stefan R. Hansson *, Åsa Nääv and Lena Erlandsson \\ Department of Obstetrics and Gynecology, Institute for Clinical Sciences, Lund University, Lund, Sweden
}

\section{Edited by:}

Sruti Shiva, University of Pittsburgh, USA

\section{Reviewed by:}

Cameron Rink, The Ohio State

University Wexner Medical Center, USA

Deepesh Pandey, Georgia Health

Sciences University, USA

${ }^{*}$ Correspondence:

Stefan R. Hansson, Department of Obstetrics and Gynecology, Institute for Clinical Sciences, Lund University, BMC C14, Klinikgatan 28, SE-221 85 Lund, Sweden

e-mail: stefan.hansson@med.lu.se
Preeclampsia is a leading cause of pregnancy complications and affects 3-7\% of pregnant women. This review summarizes the current knowledge of a new potential etiology of the disease, with a special focus on hemoglobin-induced oxidative stress. Furthermore, we also suggest hemoglobin as a potential target for therapy. Gene and protein profiling studies have shown increased expression and accumulation of free fetal hemoglobin in the preeclamptic placenta. Predominantly due to oxidative damage to the placental barrier, fetal hemoglobin leaks over to the maternal circulation. Free hemoglobin and its metabolites are toxic in several ways; (a) ferrous hemoglobin $\left(\mathrm{Fe}^{2+}\right)$ binds strongly to the vasodilator nitric oxide (NO) and reduces the availability of free NO, which results in vasoconstriction, (b) hemoglobin $\left(\mathrm{Fe}^{2+}\right)$ with bound oxygen spontaneously generates free oxygen radicals, and (c) the heme groups create an inflammatory response by inducing activation of neutrophils and cytokine production. The endogenous protein a1-microglobulin, with radical and heme binding properties, has shown both ex vivo and in vivo to have the ability to counteract free hemoglobin-induced placental and kidney damage. Oxidative stress in general, and more specifically fetal hemoglobin-induced oxidative stress, could play a key role in the pathology of preeclampsia seen both in the placenta and ultimately in the maternal endothelium.

\section{Keywords: placenta, oxidative stress, fetal hemoglobin, hemolysis, alpha-1-microglobulin}

\section{INTRODUCTION}

Preeclampsia is a clinical syndrome that manifests during the second half of pregnancy, afflicting $3-7 \%$ of pregnant women. Preeclampsia is one of the leading causes of maternal mortality and morbidity, especially in developing countries (Mackay et al., 2001; Berg et al., 2009). The disease is clinically manifested and defined as de novo hypertension with proteinuria after 20 gestational weeks (Redman, 2011). Preeclampsia can develop into a life-threatening condition with general hemolysis, elevated liver enzymes, low platelet counts, and elevated levels of free adult hemoglobin $(\mathrm{Hb})$, classified as the HELLP syndrome (i.e., Hemolysis, Elevated Liver enzymes, Low Platelets) (Schroeder et al., 2002). Preeclampsia can further develop into eclampsia, a severe complication that is defined by the presence of seizures (Mackay et al., 2001). Currently, only symptomatic blood pressure treatment is available for preeclampsia and the only known cure to date is delivery. Hence, preeclampsia causes $\sim 15 \%$ of pre-term deliveries. Also, in $25 \%$ of cases, preeclampsia leads to intrauterine growth restriction (IUGR) of the fetus. Both

\footnotetext{
Abbreviations: A1M, alpha-1-microglobulin; IUGR, intrauterine growth restriction; HELLP, hemolysis, elevated liver enzymes, and low platelets syndrome; SOD, superoxide dismutase; $\mathrm{HO}$, hemoxygenase; $\mathrm{O}_{2}^{-}$, superoxide; $\mathrm{H}_{2} \mathrm{O}_{2}$, hydrogen peroxide; ROS, reactive oxygen species; ER, endoplasmatic reticulum; NO, nitric oxide; sFlt1, soluble fms-like tyrosine kinase 1; VEGF, vascular endothelial growth factor; PlGF, placental growth factor; TGF $\beta$, transforming growth factor-beta; sEng, soluble endoglin; RAS, renin-angiotensin system; DIC, disseminated intravascular coagulation.
}

pre-term delivery and IUGR result in infant morbidity and substantial health care expenditure (Shmueli et al., 2012). To date there is neither a diagnostic test nor screening tool available for early identification of women at risk of preeclampsia.

Several varying hypotheses and theories regarding the etiology have been put forward over the years. One hypothesis, that was suggested about 25 years ago, is that the extensive vascular endothelial dysfunction in preeclampsia is the result of circulating factors released from the placenta (Rodgers et al., 1988; Roberts et al., 1989). The fact that removal of the placenta is necessary for symptoms to regress has resulted in the theory that the placenta is central in the etiology of preeclampsia (Roberts and Hubel, 2009; Roberts and Escudero, 2012). According to the current theory, preeclampsia evolves in two stages. In brief, the first stage is characterized by a defective placentation, involving incomplete conversion of the spiral arteries by superficial ingrowth of trophoblasts in the decidua (Brosens et al., 2002). As a consequence, uneven blood perfusion, hypoxia, and oxidative stress follow. The second stage of the disease is characterized by the clinical manifestations hypertension, proteinuria, and edema, caused by maternal endothelial damage and systemic inflammation. The endothelial damage is suggested to be caused by placental-derived material or factors (Roberts et al., 1989; Tjoa et al., 2006; Redman and Sargent, 2009).

Despite intense research efforts to unveil the etiology of preeclampsia, it remains enigmatic. However, a growing body of evidence supports the understanding that the disease begins in 
the utero-placental unit, is amplified by oxidative stress, and ends in the maternal endothelium.

\section{OXIDATIVE STRESS}

Oxidative stress reflects an imbalance between the formation of oxidative substances and the innate antioxidants that make up the endogenous defense system. Oxidative substances are often free oxygen radicals and peroxides that normally form in small amounts (Buonocore et al., 2010). They can be formed in e.g., the mitochondrial respiratory chain, and when the tissue is exposed to ischemia/reperfusion injury they are produced in larger amounts. Due to their highly reactive properties, they can cause structural and functional damage to cellular DNA, proteins and cell membranes (Tjoa et al., 2006; Valko et al., 2007). In addition to oxidative stress, nitrative stress has also been documented in preeclampsia, which is the covalent modification and nitration of proteins and DNA by peroxynitrite. This occurs in the preeclamptic placenta by the release of reactive oxygen species (ROS) such as superoxide, which interacts with nitric oxide (NO) to form peroxynitrite (Myatt, 2010).

Antioxidants are molecules that inhibit the oxidation caused by oxidative substances, and they are made up of two sub-groups; enzymatic and non-enzymatic antioxidants. Examples of enzymatic antioxidants are superoxide dismutase (SOD), hemoxygenase $(\mathrm{HO})$, and catalase. SOD's enzymatic activity catalyzes the dismutation of superoxide $\left(\mathrm{O}_{2}^{-}\right)$into oxygen and hydrogen peroxide $\left(\mathrm{H}_{2} \mathrm{O}_{2}\right)$ (McCord and Fridovich, 1988). Thus, SOD is an important antioxidant defense in nearly all cells exposed to oxygen. Three isoforms of $\mathrm{HO}$ are known, where HO-1 is inducible in response to oxidative stress and catalyzes the degradation of heme. This produces biliverdin, iron, and carbon monoxide (Kikuchi et al., 2005; Ryter et al., 2006). Catalase is a common enzyme found in nearly all living organisms exposed to oxygen. It catalyzes the decomposition of $\mathrm{H}_{2} \mathrm{O}_{2}$ to water and oxygen (Chelikani et al., 2004).

Examples of non-enzymatic antioxidants are glutathione, thioredoxin, NADH, and NADPH. Glutathione is a key endogenous antioxidant that serves several functions, such as neutralization of free radicals and ROS (Pompella et al., 2003). In addition, glutathione also plays a role in keeping vitamins $\mathrm{C}$ and $\mathrm{E}$ in their reduced forms (Hughes, 1964; Scholz et al., 1989). Thioredoxin is an oxidoreductase enzyme containing a dithiol-disulfide active site that facilitates the reduction of other proteins by cysteine thiol-disulfide exchange (Holmgren, 1989; Nordberg and Arner, 2001). NADH is a coenzyme found in all living cells, and it has a role in metabolism where it is involved in redox reactions (Belenky et al., 2007). NADPH is, among other things, involved in the protection against ROS by allowing for the regeneration of reduced glutathione (Rush et al., 1985). The NADPH system is also responsible for generating free radicals in neutrophils, which is used in the destruction of pathogens (Ogawa et al., 2008).

a1-microglobulin (A1M) is both an enzymatic and a nonenzymatic antioxidant, present both intra- and extracellularly (Akerstrom and Gram, 2014). It has it's defensive function by working as an antioxidant as well as a binding protein for free radicals and heme (Allhorn et al., 2002; Olsson et al., 2008).
A1M is mainly produced in the liver, but can be found in all organs. Once produced, it is deployed to the extracellular fluids and compartments via the blood stream. The synthesis of A1M is up-regulated in response to elevated levels of free radicals, heme, and in particular by free $\mathrm{Hb}$ (Olsson et al., 2007). A1M levels are seen to increase in the preeclamptic placenta in an effort by the placenta to up-regulate its defense against increased oxidative stress (Olsson et al., 2010). The protein prevents oxidation and oxidative damage to cells and matrix molecules, and removes heme from cell membranes and cytosol (Olsson et al., 2008).

\section{OXIDATIVE STRESS AND PREECLAMPSIA}

In preeclampsia, evidence of oxidative stress can be seen both in the maternal circulation and in the placenta. Placentas from women with preeclampsia have reduced antioxidant capacity compared to normal placentas (Wang and Walsh, 1996; Walsh, 1998). Furthermore, levels of antioxidants in blood from women with preeclampsia have been shown to be reduced, as well as levels of oxidative modifications of proteins and lipoprotein particles (Hubel, 1999; Raijmakers et al., 2004).

Placental trophoblasts and endothelial cells constitute the placental barrier, which effectively separates the fetal and maternal circulation. Oxidative stress and tissue damage is suggested to cause a breach in the barrier and create a leakage of fetal and placenta-derived factors and/or material into the maternal circulation. In stage two of the disease the shedding of placental debris leads to maternal endothelial damage, elevated oxidative stress, and systemic inflammation (Smarason et al., 1993; Knight et al., 1998; Hahn and Holzgreve, 2002; Tjoa et al., 2006). An additional cause to inflammation and vascular damage is the shedding of microparticles from the placenta, induced by placental abnormalities and utero-placental ischemia. The content of the microparticles, such as free $\mathrm{Hb}$ and miRNA can further aggravate the systemic oxidative stress (Redman and Sargent, 2008; Tannetta et al., 2013; Cronqvist et al., 2014; Rudov et al., 2014).

Women living at high altitude alter the normal oxygen balance and are shown to have increased risk of developing preeclampsia (Palmer et al., 1999). The effect of oxidative stress on female reproduction has been explored in relation to infertility and assisted reproductive techniques (Agarwal et al., 2012). Pregnancy complications such as recurrent pregnancy loss and spontaneous abortion can develop in response to oxidative stress (Jauniaux et al., 2000; Poston and Raijmakers, 2004). Maternal obesity has also been associated with an increased risk of preeclampsia (Wolf et al., 2001), which could be partly mediated by the increased level of oxidative stress present in obesity (Zavalza-Gomez, 2011). Smoking causes oxidative stress and is an established risk factor for cardio-vascular disease. In pregnant women, smoking causes increased risk of IUGR. However, smoking has also been associated with a protective effect against preeclampsia (CondeAgudelo et al., 1999). A suggested explanation could be that the observed lower level of sFlt1 in smokers compared to nonsmokers is due to the suppression of sFlt1 by carbon monoxide (Karumanchi and Levine, 2010). This is in line with the elevated levels of sFlt1 observed in women with preeclampsia (Levine et al., 2006). 


\section{OXIDATIVE STRESS CAUSES CELLULAR AND SYSTEMIC EFFECTS \\ CELLULAR LEVEL}

The degree to which the implantation and the conversion of the spiral arteries are deficient has been postulated to influence the degree of oxidative stress and endoplasmic reticulum (ER) stress. Oxidative stress disturbs the normal redox state of the cell, which causes toxic effects on all cellular components, including proteins, lipids, and DNA, and more severe oxidative stress can result in cell death (Valko et al., 2007). During ER stress, unfolded and misfolded proteins accumulate in the ER and activate ER stressresponse pathways, also known as the unfolded protein response (Yung et al., 2014). Preeclamptic placentas have been shown to accumulate clusters of misfolded proteins and it is speculated that these aggregates may contribute to the pathophysiology of the disease. The misfolded proteins can also be detected in urine, as a potential biomarker by the Congo red dot test (Buhimschi et al., 2014). ER stress has been shown to be associated with the small placental phenotype in both preeclampsia and IUGR (Burton et al., 2009).

\section{SYSTEMIC LEVEL}

Inflammation in response to oxidative stress is mediated by the recruitment of leukocytes and the production of proinflammatory cytokines, adhesion molecules (ICAM-1 and VCAM-1), and chemokines. This cascade of events is preceded by the presence of heme, which causes production of ROS (Lavrovsky et al., 1994; Markus et al., 2007). Heme has also been shown to induce inflammation via the Toll-like receptors (Belcher et al., 2014).

Endothelial function is affected by the oxidative burden. Superoxide inactivates NO, leading to an increase in peroxynitrite as well as a reduced bioactivity of NO. Furthermore, free $\mathrm{Hb}$ can also bind NO (Kim-Shapiro et al., 2006). The depletion of $\mathrm{NO}$ results in a series of downstream events, such as impaired endothelium-dependent vasodilation or vasoconstriction, lipoprotein accumulation and oxidative modification, intravascular inflammation and release of pro-inflammatory and vasoactive mediators (Motterlini et al., 1995; Madamanchi et al., 2005). The contents of placental microparticles released into the maternal circulation during preeclampsia also contributes to the elevated level of systemic oxidative stress (Redman and Sargent, 2008; Tannetta et al., 2013; Cronqvist et al., 2014; Rudov et al., 2014).

Primipara women have an increased risk of preeclampsia while pre-conception exposure to paternal antigen gives a reduced risk, implicating an immunological component in the etiology of the syndrome. During the first stage of preeclampsia, maternal adaptation and tolerance to fetal antigen has been suggested to be crucial (Redman and Sargent, 2010).

\section{ANTIOXIDANT PROTECTIVE SYSTEMS}

The human body relies on several antioxidant protective systems. Uric acid is a powerful antioxidant in the human plasma and is a scavenger of free oxygen and radicals. It reduces the oxoheme oxidant formed by peroxide reaction with $\mathrm{Hb}$ and protects erythrocytes from peroxidative damage leading to lysis (Ames et al., 1981). The uric acid level both predicts and correlates with the development of conditions associated with oxidative stress (Sautin and Johnson, 2008) and is suggested to be a marker for oxidative stress (Becker, 1993). Therefore, the concentration of serum uric acid in pregnant women with preeclampsia has been suggested to be associated with disease severity (Pereira et al., 2014).

Vitamins $\mathrm{C}$ and $\mathrm{E}$ are described as antioxidants against oxidative stress, and their effect on the reduced antioxidant capacity in placentas from women with preeclampsia has been tested in large randomized trials (Poston et al., 2006; Rumbold et al., 2006; Villar et al., 2009; Conde-Agudelo et al., 2011). However, supplementation with vitamins $\mathrm{C}$ and $\mathrm{E}$ during pregnancy could not be shown to reduce the risk of preeclampsia (Spinnato, 2006).

The compound magnesium sulfate $\left(\mathrm{MgSO}_{4}\right)$ is used as a drug to treat and prevent seizures in severe preeclampsia and eclampsia (Sibai, 2005; Kassie et al., 2014). It has been shown to have a mild vasodilator effect in the maternal circulation (Sontia and Touyz, 2007; Souza et al., 2010) as well as a protective effect on endothelial cells (Kharitonova et al., 2015). It has also been shown to restore cerebral oxygenation impairment seen in patients with severe preeclampsia (Guerci et al., 2014). The exact mechanism of action for $\mathrm{MgSO}_{4}$ is not yet understood, but a role as an antioxidant has recently been suggested.

From a clinical perspective it would be of great interest to gain a deeper understanding of the impact of environmental pollutants as well as the influence of nutrients and micronutrients on the oxidative balance in pregnancy in general and preeclampsia in particular (Mistry and Williams, 2011). Exposure to air pollution, especially to ultra-fine particles has been shown to induce oxidative stress (Terzano et al., 2010). Furthermore, a positive association between preeclampsia and exposure to air pollutants, such as nitrogen oxides, nitrogen monoxide, nitrogen dioxide, carbon monoxide, ozone, particulate matter of $<2.5 \mu \mathrm{m}$ and particulate matter of $<10 \mu \mathrm{m}$, has been shown in recent studies (Wu et al., 2009, 2011; Lee et al., 2013; Malmqvist et al., 2013).

Deficiency of micronutrients such as selenium, copper $(\mathrm{Cu})$, zinc $(\mathrm{Zn})$, and manganese $(\mathrm{Mn})$ during pregnancy can affect antioxidant capacities in the mother and contribute to poor pregnancy outcomes e.g., preeclampsia (Rumbold et al., 2008). The antioxidant defenses found in placenta includes the selenium-dependent glutathione peroxidases, thioredoxin reductases, selenoprotein-P, and $\mathrm{Cu} / \mathrm{Zn}$ and Mn SOD's (Wang and Walsh, 1996; Vanderlelie et al., 2005; Rayman, 2009). Studies have shown a correlation between low serum selenium concentrations and reduced antioxidant function in preeclampsia, suggesting that selenium status is important. This is further supported by placebo-controlled randomized controls trials where pregnant women were given selenium supplementation, resulting in lower incidence of pregnancy-induced hypertension and/or preeclampsia (Han and Zhou, 1994; Rumiris et al., 2006). Cu is an essential cofactor for several important enzymes including catalase and SOD (Gambling et al., 2008). Cu is a redoxactive transition metal with pro-oxidant properties and can catalyze the formation of free radicals, thereby inducing oxidative stress in preeclampsia (Serdar et al., 2006). However, when 
$\mathrm{Cu}$ is associated in the $\mathrm{Cu} / \mathrm{Zn} \mathrm{SOD}$ it functions as an antioxidant expressed in both maternal and fetal tissue (Ali Akbar et al., 1998). Studies have shown increased levels of $\mathrm{Cu}$ in placenta, maternal serum, and amniotic fluid in preeclamptic women compared to controls (Brophy et al., 1985; Dawson et al., 1999; Serdar et al., 2006). However, data on Cu status throughout normal pregnancies as well as early preeclamptic pregnancies is inadequate, and it remains unclear whether $\mathrm{Cu}$ deficiency is a public health problem (Arredondo and Nunez, 2005).

$\mathrm{Zn}$ has antioxidant functions through the $\mathrm{Cu} / \mathrm{Zn} \mathrm{SOD}$ (Izquierdo Alvarez et al., 2007). Zn supplementation studies show reduced incidence of pregnancy induced hypertension (Goldenberg et al., 1995), and Zn deficiency has been associated with preeclampsia with decreased levels in placental tissue and maternal serum (Brophy et al., 1985; Dawson et al., 1999; Kumru et al., 2003). Mn is also a cofactor for important enzymes, such as the antioxidant Mn SOD which is involved in protection against oxidative stress in the placenta (Ademuyiwa et al., 2007). Studies have indicated that whole blood Mn concentrations are lower in women with fetal growth restriction (Vigeh et al., 2008). Furthermore, umbilical cord whole blood in preeclampsia has been shown to have reduced levels of Mn (Jones et al., 2010).

Dietary nitrate, in e.g., beetroot juice, is converted in vivo to bioactive nitrogen oxides such as $\mathrm{NO}$ and may be used as nitrate supplementation (Lundberg et al., 2008). It has been shown to reduce blood pressure, increase blood flow, and modulate oxidative stress (Webb et al., 2008; Carlstrom et al., 2011; Lundberg et al., 2011). Beetroot juice has recently been shown to improve placental vascular function during pregnancy in mice (Cottrell et al., 2014).

\section{FETAL HEMOGLOBIN IN THE PATHOGENESIS OF PREECLAMPSIA}

With the use of microarray and proteomics technologies we studied gene expression in placentas from normal patients and patients with preeclampsia. Through the use of a subtraction library, a total of 750 preeclampsia-associated genes were identified, which were used to manufacture analytical chips for microarray analysis (Centlow et al., 2008). Increased expression of genes involved in inflammation, apoptosis, and oxidative stress were found in the preeclamptic placentas. More specifically, an increased expression of fetal $\mathrm{Hb}(\mathrm{HbF})$, seen as both elevated mRNA and accumulation of the protein, was reported (Figure 1). In situ hybridization and immunohistochemistry were used to localize the cells that expressed HbF in the placenta, and these were identified as hematopoietic stem cells located to the vascular lumen (Figure 1).

\section{FREE HEMOGLOBIN CAUSES OXIDATIVE STRESS}

$\mathrm{Hb}$ is composed of four globin chains, each with an embedded iron-containing heme group with a high affinity to oxygen. The most common variants of the globin chains are $\alpha, \beta$, and $\gamma$, and that are used differently during normal embryonic and fetal development. HbF consists of two $\alpha$ - and two $\gamma$-chains and is the main $\mathrm{Hb}$ form in fetuses, being expressed from approximately gestational week 10 to birth. $\mathrm{HbF}$ comprises $<1 \%$ of the $\mathrm{Hb}$ in adults. Adult $\mathrm{Hb}(\mathrm{HbA})$ consists of two $\alpha$ - and two $\beta$-chains, and makes up $>95 \%$ of the Hb after 6 months of age.

The redox activity of the iron atom in the heme group serves as the basis for the strong oxidative reactivity of free $\mathrm{Hb}$. Free $\mathrm{Hb}$ is defined as extracellular unbound Hb. During hemolysis, erythrocytes rupture and free Hb leaks out into the circulation.
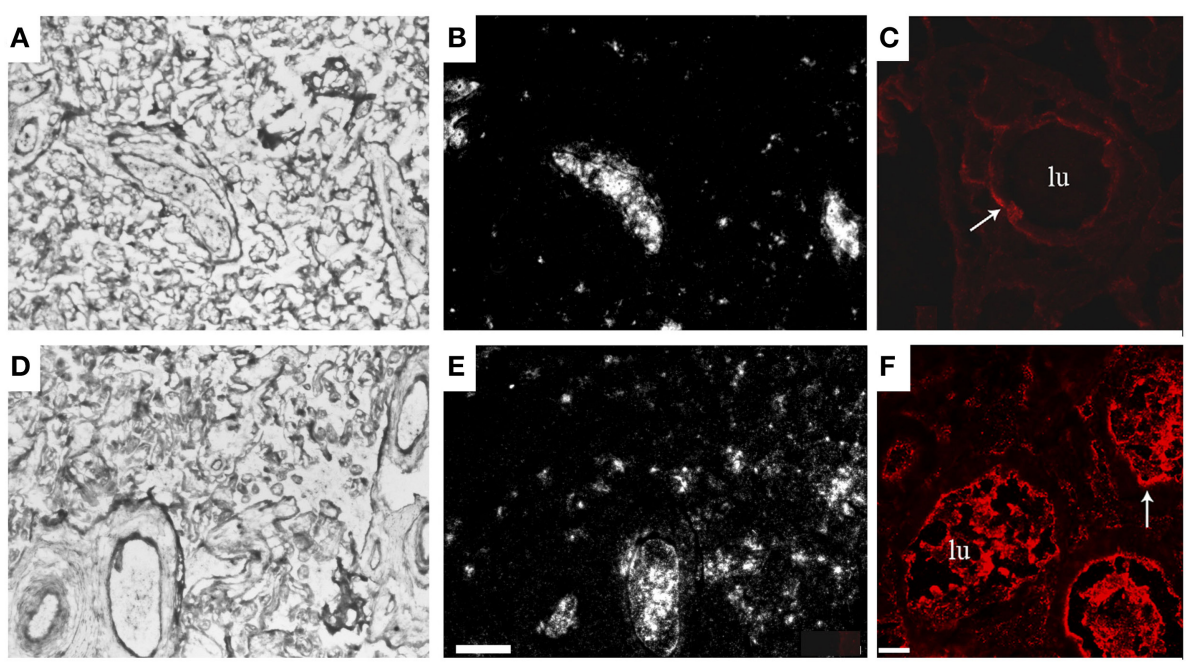

FIGURE 1 | Increased placental expression of $\mathrm{HbF}$ in preeclampsia. Representative images from in situ hybridizations of human placenta, displaying the villous section of the placenta. HbF mRNA expression ( $\alpha$-chain) in a control placenta shown as light field image (A) and as dark field image (B), and in a preeclamptic placenta shown as light field image (D) and as dark field image (E). HbF expression was especially seen in and around blood vessels, with several scattered cells detected in the villous section of the preeclamptic placenta. HbF protein expression $(\gamma$-chain) is shown with a red fluorescent marker in control placenta (C) and in preeclamptic placenta (F). In the preeclamptic placenta there is a strong expression of $\mathrm{HbF}$ in the vascular lumen (lu), but $\mathrm{HbF}$ is also expressed in the vascular endothelium (arrow) as well as in the extravascular section of the villous stroma. The placenta from control shows no expression of $\mathrm{HbF}$ in the vascular lumen (lu), but expression is detected in the vascular endothelium (arrow). Scale bars for $\mathbf{( A , B , D , E ) =}$ $100 \mu \mathrm{m}$ and for $(\mathbf{C}, \mathbf{F})=25 \mu \mathrm{m}$. Modified from Centlow et al. (2008). 
Eryptosis is a suicidal erythrocyte death, stimulated by oxidative stress, energy depletion, calcium imbalance, and a wide range of xenobiotic compounds. It is inhibited by erythropoietin and NO (Lang et al., 2012). Eryptosis affects the capillary beds by fostering thrombosis. It is seen in several systemic conditions such as diabetes, renal insufficiency and malaria, conditions well-known as risk factors for preeclampsia.

The vasoconstrictive effect of free $\mathrm{Hb}$ is a result of the ferrous $\mathrm{Hb}\left(\mathrm{Fe}^{2+}\right)$ binding strongly to the vasodilator $\mathrm{NO}$, thereby reducing the availability of NO. Currently, NO donors are being investigated in clinical trials as therapeutics for IUGR and preeclampsia (Cindrova-Davies, 2014). $\mathrm{Hb}\left(\mathrm{Fe}^{2+}\right.$ ) with bound oxygen $(\mathrm{OxyHb})$ spontaneously generates free oxygen radicals. This results in aggregated and oxidized forms of the molecule, degradation products, and free iron and heme groups. As a result, $\mathrm{Hb}$ and its degradation products are toxic and can cause oxidative stress, hemolysis, vasoconstriction, kidney, and vascular endothelial damage (Buehler and D'Agnillo, 2010). Heme groups have a direct effect on the inflammatory response by inducing activation of neutrophils and induction of cytokine production (Kumar and Bandyopadhyay, 2005).

Several defense mechanisms exist to protect against the harmful effects of free $\mathrm{Hb}$. Antioxidants such as vitamins $\mathrm{C}$ and $\mathrm{E}$ protect against oxidative stress. The blood plasma scavenger proteins haptoglobin and hemopexin bind free $\mathrm{Hb}$ and free heme groups, respectively, and the formed complexes are eliminated from the blood by cellular uptake via the two receptor-mediated pathways CD163 on macrophages and CD91 in the liver (Kristiansen et al., 2001; Ascenzi et al., 2005). In fact, haptoglobin levels are reduced in preeclampsia, indicating a depletion of the protective systems against free $\mathrm{Hb}$ (Olsson et al., 2010).

\section{FREE HEMOGLOBIN CAUSES PLACENTAL DAMAGE}

Recently our group has shown that free $\mathrm{Hb}$ is a potential key factor in the pathogenesis of preeclampsia. By aggravating oxidative stress, causing damage to the placental barrier and leaking into the maternal bloodstream, it causes endothelial damage and vasoconstriction (Centlow et al., 2008; May et al., 2011). To study the toxic effect of free $\mathrm{Hb}$ on placental tissue, the placenta perfusion model was used. This well-documented ex vivo system mimics the pregnant in vivo situation in humans in a way not possible by using placenta cell culture or animal models (Schneider and Huch,
1985; Di Santo et al., 2007). In this system, free Hb was added to the fetal circulation. A preeclampsia-like situation developed within $10 \mathrm{~min}$, displaying a steep increase in blood pressure. Signs of placental barrier breach appeared after $\sim 1$ h of perfusion, with leakage of nutrients from the fetal circulation into the maternal circulation. Transmission electron microscopy (TEM) confirmed the tissue damage with considerable damage to the extracellular matrix, with an almost complete elimination of the collagen fibrils that maintain the tissue structure (Figure 2). Further, there were widespread cellular changes with damage to membranes, nuclei and mitochondria, and formation of apoptotic vesicles and vacuoles. Gene profiling of placentas perfused with free $\mathrm{Hb}$ showed a similar genetic profile as women with preeclampsia. These ex vivo findings suggest that free $\mathrm{Hb}$ plays an important role in the disease etiology (Centlow et al., 2009; May et al., 2011). To further study the effects of free HbF, we established a pregnant rabbit preeclampsia model where pregnant rabbits were infused with species-specific free $\mathrm{HbF}$, starting at mid-gestation until term. TEM analysis of the placenta revealed structural damages with a dramatic reduction of the collagen fibers in the extracellular matrix, as well as cellular damages such as mitochondrial swelling, aberrant intracellular nuclear membranes, damaged electron dense barrier, and high levels of apoptotic bodies (Figure 3). In the pregnant ewe preeclampsia model, starvation induces preeclampsia-like symptoms by causing hemolysis with subsequent release of free $\mathrm{Hb}$ (Wester-Rosenlof et al., 2014). Also in this model TEM analysis could confirm tissue damage in placentas from starved ewes, with an almost complete elimination of the collagen fibers as well as cellular damages (Wester-Rosenlof et al., 2014).

\section{FREE HEMOGLOBIN CAUSES KIDNEY DAMAGE}

The proteinuria in preeclampsia is associated with glomerular injuries in the kidney, known as glomerular endotheliosis. Endotheliosis includes swelling of endothelial cells and loss of endothelial fenestration, as well as occlusion of capillary lumens in some cases (Lafayette et al., 1998; Stillman and Karumanchi, 2007). Podocytes form the slit diaphragm, which is crucial for maintaining the size-selective nature of the glomerular filtration barrier in the kidney, and alterations in the podocytes have been associated with proteinuria in preeclampsia (Garovic et al., 2007; Henao et al., 2008; Henao and Saleem, 2013).
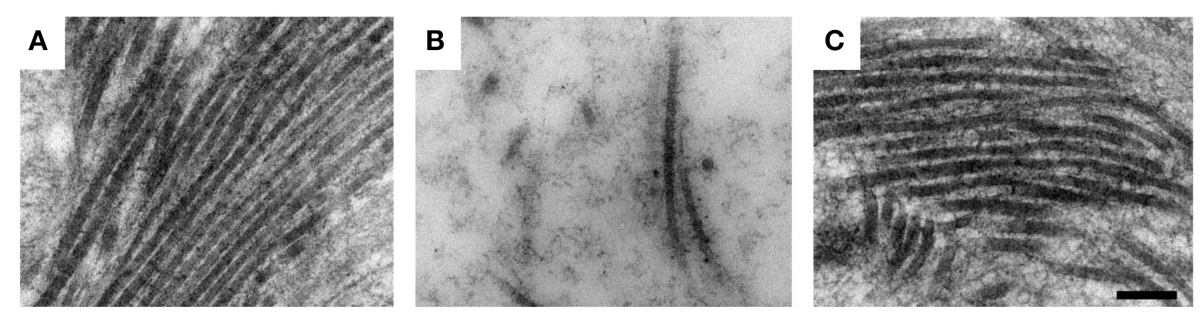

FIGURE 2 | Free $\mathrm{Hb}$ causes placental damage ex vivo which can be ameliorated by $\mathbf{A} \mathbf{1 M}$. Transmission electron microscopy analysis of ex vivo perfused human placenta. (A) Non-perfused human placenta. (B) Free $\mathrm{Hb}$ was added to the fetal circulation and caused severe damage to the extracellular matrix with an almost complete elimination of the collagen fibers. (C) $\mathrm{A} 1 \mathrm{M}$ was added to the maternal circulation at the same time as $\mathrm{Hb}$ was added to the fetal circulation, and prevented the damaging effects of $\mathrm{Hb}$ on the extracellular matrix, displaying normal collagen fibers. Scale bars: $200 \mu \mathrm{m}$. Adapted from May et al. (2011). 

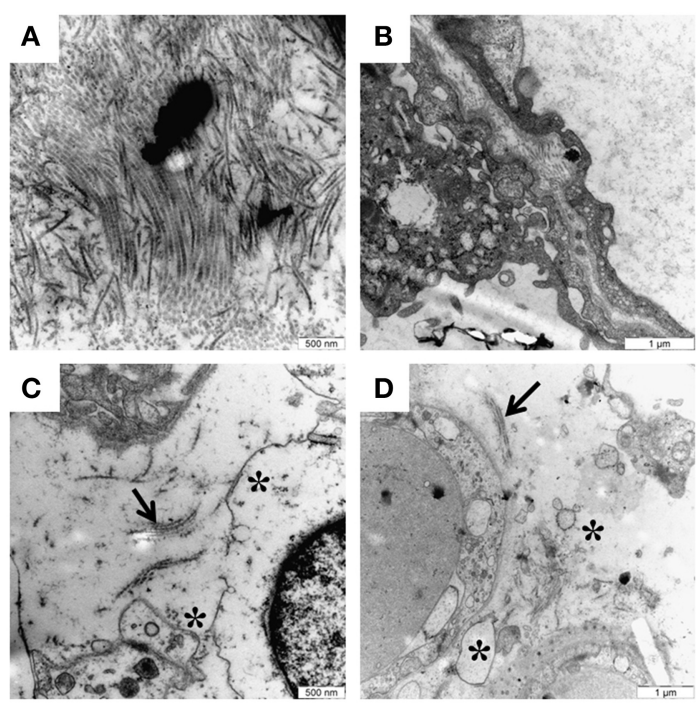

FIGURE 3 | Free HbF causes structural and cellular damage to placenta tissue in vivo. Transmission electron microscopy analysis of placenta tissue from pregnant rabbits infused with free $\mathrm{HbF}$. (A,B) Normal placental tissue from control animals showing extracellular matrix with dense bundles of collagen fibers. (C,D) HbF causes severe damage to the extracellular matrix with loss of collagen fibers (indicated by arrows), extracellular apoptotic bodies, cell debris and a lot of empty extracellular space (indicated by stars). Scale bars: $(\mathbf{A}, \mathbf{C})=500 \mathrm{~nm}$; $(\mathbf{B}, \mathbf{D})=1 \mu \mathrm{m}$.

This indicates that podocytes are a crucial part in explaining the loss of filtration capacity in the preeclamptic kidneys. Podocyturia has also been associated with preeclampsia (Garovic et al., 2007). Glomerular endotheliosis has long been considered pathognomonic for preeclampsia (Stillman and Karumanchi, 2007), however, these changes have also been observed, albeit to a lesser extent, by pregnancy-induced hypertension (absence of proteinuria) and in normal pregnancy (Strevens et al., 2003). Furthermore, changes to the podocytes, and their interaction with the glomerular endothelium has recently been shown to be important in the onset of proteinuria and podocyturia (Wagner et al., 2012; Craici et al., 2013). In a mouse knockout model where podocytes lack VEGF, endotheliosis, and proteinuria were seen (Eremina et al., 2003). The capillary leakage in the glomeruli contributes to the observed proteinuria. It is further shown that the renin-angiotensin system (RAS) plays a role in the development of hypertension by an increased vascular response to angiotensin II (Wang et al., 2009; Rodriguez et al., 2012). Autoantibodies against the angiotensin II AT1 receptor has been shown in preeclampsia (Dechend et al., 2005; Karumanchi and Lindheimer, 2008).

In severe forms of preeclampsia/HELLP/eclampsia, the damaged endothelium activates platelets and the coagulation system, which may cause sub-acute/acute disseminated intravascular coagulation (DIC) (Thachil and Toh, 2009). In DIC, there is a dysregulation of coagulation and fibrinolysis causing decreased platelet count and fibrinogen levels, and increased consumption of antithrombin. Especially in the kidneys and the liver, a gradual fibrin formation occurs.
Patients with preeclampsia exhibit a reduced glomerular filtration rate. Behind this lies a partly reduced renal blood flow and a reduced filtration area caused by reduced fenestration in the glomerular endothelium and fibrin deposits. In the HELLP syndrome, acute kidney injury is seen in approximately $3-15 \%$ of cases (Fakhouri et al., 2012), where glomerular endotheliosis and acute tubular necrosis are typical findings. The acute high level of free $\mathrm{Hb}$ is likely to contribute to the kidney damage. To study the effect of free $\mathrm{HbF}$ on the function of a normal rat kidney in vivo, free HbF was systemically infused into rats and the permeability of the glomerular filtration barrier in the kidney was studied (Sverrisson et al., 2014). Our findings demonstrate that free $\mathrm{HbF}$ induces an increase in the glomerular permeability to macromolecules through the induction of oxidative stress. This change is believed to occur via a direct interaction between $\mathrm{HbF}$ and the endothelium via ROS and/or NO (Sverrisson et al., 2014). Also, in the pregnant ewe preeclampsia model, free $\mathrm{Hb}$ induced an increase in the glomerular permeability as well as typical glomerular endotheliosis (Wester-Rosenlof et al., 2014) (Figure 4). Other hemolytic diseases such as autoimmune hemolytic anemia, sickle cell anemia and malaria are also known to cause kidney disease (Bunn et al., 1977).

\section{A1M COUNTERACTS TISSUE DAMAGE CAUSED BY FREE Hb}

In several recent studies our group has evaluated the protective effect and the therapeutic potential of A1M. Using the ex vivo placenta perfusion model described above (May et al., 2011), preeclampsia-like symptoms developed shortly after perfusion of free $\mathrm{Hb}$ to the fetal circulation. To evaluate the potential therapeutic effect, A1M was added to the maternal circulation of the perfused placenta in an attempt to mimic a potential future intravenous therapy. A1M reversed the damages caused by free $\mathrm{Hb}$, where the $\mathrm{Hb}$ leakage from the fetal to the maternal circulation ceased completely, and no structural damages to the placental tissue were detected (Figure 2). Gene profiling showed that genes coding for the structural components of the extracellular matrix were up-regulated, suggesting that a healing process was initiated by A1M.

The role of $\mathrm{A} 1 \mathrm{M}$ was further studied in two different in vivo animal models. In the first study, systemically infused free $\mathrm{HbF}$ in rats caused an increase in the glomerular permeability to macromolecules in the kidney through the induction of oxidative stress. This was counteracted by A1M and resulted in a restored glomerular filtration barrier (Sverrisson et al., 2014). The pregnant ewe preeclampsia model was also used to evaluate the therapeutic potential of A1M (Wester-Rosenlof et al., 2014). In this model, free $\mathrm{Hb}$ induced preeclampsia-like symptoms and intravenous infusion with A1M ameliorated the structural tissue damages seen in both kidney (Figure 4) and placenta, as well as restored the glomerular filtration rate in the kidney.

\section{OTHER CONTRIBUTORY FACTORS TO THE DEVELOPMENT OF PREECLAMPSIA}

The maternal injured or activated endothelium in preeclampsia has been shown to release several factors including endothelin-1, fibronectin, von Willebrand factor, thrombomodulin, markers of oxidative stress and inflammatory cytokines (Musci et al., 1988; 

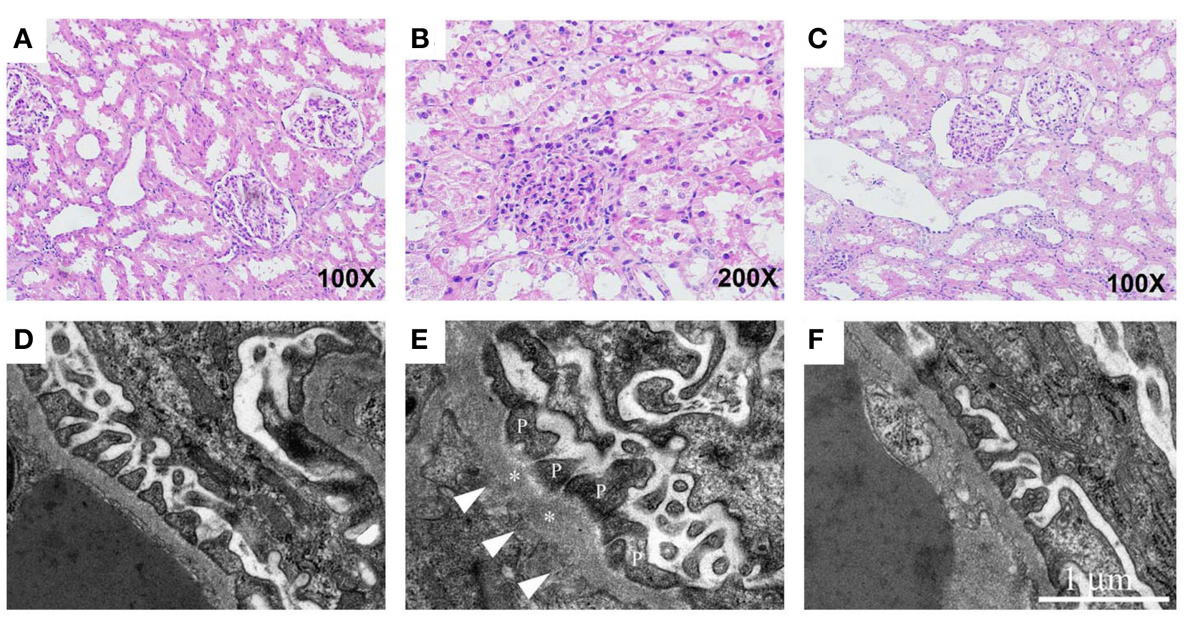

FIGURE 4 | Free Hb causes kidney damage in pregnant ewes which can be ameliorated by $\mathbf{A} 1 \mathbf{M}$. The renal tissue from starved pregnant ewes was studied by light microscopy on cortical specimens stained with hematoxylin and eosin (A-C) and by transmission electron microscopy (D-F). (A) Normal cortical tissue morphology in control ewes. The renal tubules show minor signs of postmortem changes but the height of the epithelium is normal, and only discrete cytoplasmic vacuolization's are seen. The glomeruli demonstrate open capillary loops and no signs of segmentation. (B) Clear signs of glomerular endothelial swelling, seen as closure of capillary loops, and non-isometric vacuolization of the tubular epithelium in the starved ewes.
(C) In the A1M-treated starved ewes, only small tubular changes compatible with acute tubular necrosis are present and to a milder degree than seen in starved ewes. Also, no signs of glomerular endothelial swelling can be seen. (D) Normal ultrastructure of the glomerular area in control ewes. (E)

Disturbed morphology of the podocytes in the starved animals. The arrows point at abnormal regions on the basement membrane with fenestrations underneath. The asterisks mark the basal membrane and $P$ indicates the podocyte foot extensions. (F) Normalized ultrastructure was observed after A1M treatment. Magnification: (A,C) 100×; (B) 200×. Scale bars: (D-F) $1 \mu \mathrm{m}$. Adapted from Wester-Rosenlof et al. (2014).
Thorp et al., 1990; Nova et al., 1991; Taylor et al., 1991; Hsu et al., 1993; Minakami et al., 1993; Deng et al., 1994; Cackovic et al., 2008). Other factors with vasodilation properties, e.g., NO and prostacyclin have been reported to be reduced in preeclampsia while factors such as angiotensin II and thromboxane have been shown to be elevated. This imbalance between vasodilation and vasoconstriction factors contributes to increased vasoconstriction and hypertension (Lowe, 2000; Ariza et al., 2007).

Endothelial damage also triggers the activation of the coagulation system. Increased thrombocyte activity is seen in preeclampsia, which in severe cases can lead to DIC (Thachil and Toh, 2009). Thrombosis in the placental vessels further impairs vascular perfusion, leading to a negative spiral of illness. In addition, the leaking fetal and placental factors are usually foreign to the maternal immune system, further contributing to the inflammation that aggravates the endothelial damage (Rusterholz et al., 2007; Redman and Sargent, 2009; Messerli et al., 2010).

Signs of chronic inflammation, increased dendritic cell numbers and macrophage infiltration are seen in the preeclamptic placenta, indicating a pathological immune response (Salafia et al., 1995; Hiby et al., 2004; Lockwood et al., 2006; Huang et al., 2008). Paternal antigen exposure has been shown to be a risk factor for preeclampsia. In addition, women with an incomplete or disturbed immune system (e.g., untreated HIV positive women) are less likely to develop preeclampsia, further suggesting an immunological dysfunction to be part of the etiology of preeclampsia (Wimalasundera et al., 2002).

Another active area of investigation focuses on the role of angiogenic factors such as sFlt1, VEGF, PlGF, TGF $\beta$, and sEng in preeclampsia. The maintenance of a healthy vascular endothelium relies on a proper balance between proangiogenic and antiangiogenic factors released during pregnancy. Discordance in these has been postulated to be a possible cause of endothelial dysfunction seen in preeclampsia (Kendall and Thomas, 1993; Kendall et al., 1996; Clark et al., 1998; Wimalasundera et al., 2002; Levine et al., 2006; Sela et al., 2008; Heydarian et al., 2009; Thomas et al., 2009; Walshe et al., 2009).

\section{CONCLUDING REMARKS}

The prevailing theory is that preeclampsia is a syndrome that starts in the placenta and ends in the maternal endothelium. As reviewed here, oxidative stress in general, and more specifically oxidative stress induced by free $\mathrm{HbF}$, could play a key role in the pathological mechanisms in both the placenta and ultimately the maternal endothelium as seen in preeclampsia. Gene and protein profiling studies have shown that free $\mathrm{HbF}$ forms and accumulates in the placenta in preeclampsia.

Oxidative stress appears to hold a central position during stage one of preeclampsia, and contributes to the clinical manifestations during stage two of the syndrome. Oxidative stress is amplified in a vicious circle of overproduction and release of $\mathrm{Hb}$, free $\mathrm{HbF}$ in preeclampsia and free HbA in the HELLP syndrome. The maternal constitutional factors can either predispose or protect against the increased oxidative stress. Depending on the individual constitutional factors, the same oxidative insult may give rise to several manifestations and forms of preeclampsia, as well as varying severity.

The endogenous A1M protein, with radical and heme binding properties, has shown both ex vivo and in vivo to have the ability to counteract free $\mathrm{Hb}$-induced placental and kidney damage, and 
to restore both placental barrier and glomerular filtration barrier functions.

\section{REFERENCES}

Ademuyiwa, O., Odusoga, O. L., Adebawo, O. O., and Ugbaja, R. (2007). Endogenous antioxidant defences in plasma and erythrocytes of pregnant women during different trimesters of pregnancy. Acta Obstet. Gynecol. Scand. 86, 1175-1182. doi: 10.1080/00016340701515357

Agarwal, A., Aponte-Mellado, A., Premkumar, B. J., Shaman, A., and Gupta, S. (2012). The effects of oxidative stress on female reproduction: a review. Reprod. Biol. Endocrinol. 10:49. doi: 10.1186/1477-7827-10-49

Akerstrom, B., and Gram, M. (2014). AlM, an extravascular tissue cleaning and housekeeping protein. Free Radic. Biol. Med. 74C, 274-282. doi: 10.1016/j.freeradbiomed.2014.06.025

Ali Akbar, S., Nicolaides, K. H., and Brown, P. R. (1998). Measurement of Cu/Zn SOD in placenta, cultured cells, various fetal tissues, decidua and semen by ELISA. J. Obstet. Gynaecol. 18, 331-335. doi: 10.1080/01443619867056

Allhorn, M., Berggard, T., Nordberg, J., Olsson, M. L., and Akerstrom, B. (2002). Processing of the lipocalin alpha(1)-microglobulin by hemoglobin induces heme-binding and heme-degradation properties. Blood 99, 1894-1901. doi: 10.1182/blood.V99.6.1894

Ames, B. N., Cathcart, R., Schwiers, E., and Hochstein, P. (1981). Uric acid provides an antioxidant defense in humans against oxidant- and radical-caused aging and cancer: a hypothesis. Proc. Natl. Acad. Sci. U.S.A. 78, 6858-6862. doi: 10.1073/pnas.78.11.6858

Ariza, A. C., Bobadilla, N. A., and Halhali, A. (2007). [Endothelin 1 and angiotensin II in preeeclampsia]. Rev. Invest. Clin. 59, 48-56.

Arredondo, M., and Nunez, M. T. (2005). Iron and copper metabolism. Mol. Aspects Med. 26, 313-327. doi: 10.1016/j.mam.2005.07.010

Ascenzi, P., Bocedi, A., Visca, P., Altruda, F., Tolosano, E., Beringhelli, T., et al. (2005). Hemoglobin and heme scavenging. IUBMB Life 57, 749-759. doi: $10.1080 / 15216540500380871$

Becker, B. F. (1993). Towards the physiological function of uric acid. Free Radic. Biol. Med. 14, 615-631. doi: 10.1016/0891-5849(93)90143-I

Belcher, J. D., Chen, C., Nguyen, J., Milbauer, L., Abdulla, F., Alayash, A. I., et al. (2014). Heme triggers TLR4 signaling leading to endothelial cell activation and vaso-occlusion in murine sickle cell disease. Blood 123, 377-390. doi: 10.1182/blood-2013-04-495887

Belenky, P., Bogan, K. L., and Brenner, C. (2007). NAD+ metabolism in health and disease. Trends Biochem. Sci. 32, 12-19. doi: 10.1016/j.tibs.2006.11.006

Berg, C. J., Mackay, A. P., Qin, C., and Callaghan, W. M. (2009). Overview of maternal morbidity during hospitalization for labor and delivery in the United States: 1993-1997 and 2001-2005. Obstet. Gynecol. 113, 1075-1081. doi: 10.1097/AOG.0b013e3181a09fc0

Brophy, M. H., Harris, N. F., and Crawford, I. L. (1985). Elevated copper and lowered zinc in the placentae of pre-eclamptics. Clin. Chim. Acta 145, 107-111. doi: 10.1016/0009-8981(85)90024-5

Brosens, J. J., Pijnenborg, R., and Brosens, I. A. (2002). The myometrial junctional zone spiral arteries in normal and abnormal pregnancies: a review of the literature. Am. J. Obstet. Gynecol. 187, 1416-1423. doi: 10.1067/mob.2002.127305

Buehler, P. W., and D'Agnillo, F. (2010). Toxicological consequences of extracellular hemoglobin: biochemical and physiological perspectives. Antioxid. Redox Signal. 12, 275-291. doi: 10.1089/ars.2009.2799

Buhimschi, I. A., Nayeri, U. A., Zhao, G., Shook, L. L., Pensalfini, A., Funai, E. F., et al. (2014). Protein misfolding, congophilia, oligomerization, and defective amyloid processing in preeclampsia. Sci. Transl. Med. 6, 245ra92. doi: 10.1126/scitranslmed.3008808

Bunn, H. F., Forget, B. G., and Ranney, H. M. (1977). Hemoglobinopathies. Major Probl. Intern. Med. 12, 1-291.

Buonocore, G., Perrone, S., and Tataranno, M. L. (2010). Oxygen toxicity: chemistry and biology of reactive oxygen species. Semin. Fetal Neonatal Med. 15, 186-190. doi: 10.1016/j.siny.2010.04.003

Burton, G. J., Yung, H. W., Cindrova-Davies, T., and Charnock-Jones, D. S. (2009). Placental endoplasmic reticulum stress and oxidative stress in the pathophysiology of unexplained intrauterine growth restriction and early onset preeclampsia. Placenta 30, S43-S48. doi: 10.1016/j.placenta.2008.11.003

Cackovic, M., Buhimschi, C. S., Zhao, G., Funai, E. F., Norwitz, E. R., Kuczynski, E., et al. (2008). Fractional excretion of tumor necrosis factor-alpha in women with severe preeclampsia. Obstet. Gynecol. 112, 93-100. doi: 10.1097/AOG.0b013e31817c4304

Carlstrom, M., Persson, A. E., Larsson, E., Hezel, M., Scheffer, P. G., Teerlink, T., et al. (2011). Dietary nitrate attenuates oxidative stress, prevents cardiac and renal injuries, and reduces blood pressure in salt-induced hypertension. Cardiovasc. Res. 89, 574-585. doi: 10.1093/cvr/cvq366

Centlow, M., Carninci, P., Nemeth, K., Mezey, E., Brownstein, M., and Hansson, S. R. (2008). Placental expression profiling in preeclampsia: local overproduction of hemoglobin may drive pathological changes. Fertil. Steril. 90, 1834-1843. doi: 10.1016/j.fertnstert.2007.09.030

Centlow, M., Junus, K., Nystrom, H., May, K., Larsson, I., Olsson, M. G., et al. (2009). Perfusion of the human placenta with red blood cells and xanthine oxidase mimics preeclampsia in-vitro. Z. Geburtshilfe Neonatol. 213, 89-95. doi: 10.1055/s-0029-1224196

Chelikani, P., Fita, I., and Loewen, P. C. (2004). Diversity of structures and properties among catalases. Cell. Mol. Life Sci. 61, 192-208. doi: 10.1007/s00018003-3206-5

Cindrova-Davies, T. (2014). The therapeutic potential of antioxidants, ER chaperones, $\mathrm{NO}$ and $\mathrm{H} 2 \mathrm{~S}$ donors, and statins for treatment of preeclampsia. Front. Pharmacol. 5:119. doi: 10.3389/fphar.2014.00119

Clark, D. E., Smith, S. K., He, Y., Day, K. A., Licence, D. R., Corps, A. N., et al. (1998). A vascular endothelial growth factor antagonist is produced by the human placenta and released into the maternal circulation. Biol. Reprod. 59, 1540-1548. doi: 10.1095/biolreprod59.6.1540

Conde-Agudelo, A., Althabe, F., Belizan, J. M., and Kafury-Goeta, A. C. (1999). Cigarette smoking during pregnancy and risk of preeclampsia: a systematic review. Am. J. Obstet. Gynecol. 181, 1026-1035. doi: 10.1016/S00029378(99)70341-8

Conde-Agudelo, A., Romero, R., Kusanovic, J. P., and Hassan, S. S. (2011). Supplementation with vitamins $\mathrm{C}$ and $\mathrm{E}$ during pregnancy for the prevention of preeclampsia and other adverse maternal and perinatal outcomes: a systematic review and metaanalysis. Am. J. Obstet. Gynecol. 204, 503.e1-503.12. doi: 10.1016/j.ajog.2011.02.020

Cottrell, E., Garrod, A., Wareing, M., Dilworth, M., Finn-Sell, S., Greenwood, S., et al. (2014). Supplementation with inorganic nitrate during pregnancy improves maternal uterine artery function and placental efficiency in mice. Placenta 35, A21. doi: 10.1016/j.placenta.2014.06.071

Craici, I. M., Wagner, S. J., Bailey, K. R., Fitz-Gibbon, P. D., Wood-Wentz, C. M., Turner, S. T., et al. (2013). Podocyturia predates proteinuria and clinical features of preeclampsia: longitudinal prospective study. Hypertension 61, 1289-1296. doi: 10.1161/HYPERTENSIONAHA.113.01115

Cronqvist, T., Salje, K., Familari, M., Guller, S., Schneider, H., Gardiner, C., et al. (2014). Syncytiotrophoblast vesicles show altered micro-RNA and haemoglobin content after ex-vivo perfusion of placentas with haemoglobin to mimic preeclampsia. PLoS ONE 9:e90020. doi: 10.1371/journal.pone.0090020

Dawson, E. B., Evans, D. R., and Nosovitch, J. (1999). Third-trimester amniotic fluid metal levels associated with preeclampsia. Arch. Environ. Health 54, 412-415. doi: 10.1080/00039899909603372

Dechend, R., Gratze, P., Wallukat, G., Shagdarsuren, E., Plehm, R., Brasen, J. H., et al. (2005). Agonistic autoantibodies to the AT1 receptor in a transgenic rat model of preeclampsia. Hypertension 45, 742-746. doi: 10.1161/01.HYP.0000154785.50570.63

Deng, L., Bremme, K., Hansson, L. O., and Blomback, M. (1994). Plasma levels of von Willebrand factor and fibronectin as markers of persisting endothelial damage in preeclampsia. Obstet. Gynecol. 84, 941-945.

Di Santo, S., Sager, R., Andres, A. C., Guller, S., and Schneider, H. (2007). Dual in vitro perfusion of an isolated cotyledon as a model to study the implication of changes in the third trimester placenta on preeclampsia. Placenta 28, S23-S32. doi: 10.1016/j.placenta.2007.01.009

Eremina, V., Sood, M., Haigh, J., Nagy, A., Lajoie, G., Ferrara, N., et al. (2003). Glomerular-specific alterations of VEGF-A expression lead to distinct congenital and acquired renal diseases. J. Clin. Invest. 111, 707-716. doi: 10.1172/JCI17423

Fakhouri, F., Vercel, C., and Fremeaux-Bacchi, V. (2012). Obstetric nephrology: AKI and thrombotic microangiopathies in pregnancy. Clin. J. Am. Soc. Nephrol. 7, 2100-2106. doi: 10.2215/CJN.13121211

Gambling, L., Andersen, H. S., and McArdle, H. J. (2008). Iron and copper, and their interactions during development. Biochem. Soc. Trans. 36, 1258-1261. doi: 10.1042/BST0361258 
Garovic, V. D., Wagner, S. J., Turner, S. T., Rosenthal, D. W., Watson, W. J., Brost, B. C., et al. (2007). Urinary podocyte excretion as a marker for preeclampsia. Am. J. Obstet. Gynecol. 196, 320.el-320.e7. doi: 10.1016/j.ajog.2007.02.007

Goldenberg, R. L., Tamura, T., Neggers, Y., Copper, R. L., Johnston, K. E., Dubard, M. B., et al. (1995). The effect of zinc supplementation on pregnancy outcome. JAMA 274, 463-468. doi: 10.1001/jama.1995.03530060037030

Guerci, P., Vial, F., Feugeas, J., Pop, M., Baka, N. E., Bouaziz, H., et al. (2014). Cerebral oximetry assessed by near-infrared spectrometry during preeclampsia: an observational study: a preliminary study of the impact of magnesium sulfate administration. Crit. Care Med. 42, 2379-2386. doi: 10.1097/CCM.0000000000000519

Hahn, S., and Holzgreve, W. (2002). Fetal cells and cell-free fetal DNA in maternal blood: new insights into pre-eclampsia. Hum. Reprod. Update 8, 501-508. doi: 10.1093/humupd/8.6.501

Han, L., and Zhou, S. M. (1994). Selenium supplement in the prevention of pregnancy induced hypertension. Chin. Med. J. 107, 870-871.

Henao, D. E., Arias, L. F., Mathieson, P. W., Ni, L., Welsh, G. I., Bueno, J. C., et al. (2008). Preeclamptic sera directly induce slit-diaphragm protein redistribution and alter podocyte barrier-forming capacity. Nephron Exp. Nephrol. 110, e73-e81. doi: 10.1159/000166993

Henao, D. E., and Saleem, M. A. (2013). Proteinuria in preeclampsia from a podocyte injury perspective. Curr. Hypertens. Rep. 15, 600-605. doi: 10.1007/s11906-013-0400-1

Heydarian, M., McCaffrey, T., Florea, L., Yang, Z., Ross, M. M., Zhou, W., et al. (2009). Novel splice variants of sFlt1 are upregulated in preeclampsia. Placenta 30, 250-255. doi: 10.1016/j.placenta.2008.12.010

Hiby, S. E., Walker, J. J., O’Shaughnessy, K., M., Redman, C. W., Carrington, M., Trowsdale, J., et al. (2004). Combinations of maternal KIR and fetal HLA-C genes influence the risk of preeclampsia and reproductive success. J. Exp. Med. 200, 957-965. doi: 10.1084/jem.20041214

Holmgren, A. (1989). Thioredoxin and glutaredoxin systems. J. Biol. Chem. 264, $13963-13966$.

Hsu, C. D., Iriye, B., Johnson, T. R., Witter, F. R., Hong, S. F., and Chan, D. W. (1993). Elevated circulating thrombomodulin in severe preeclampsia. Am. J. Obstet. Gynecol. 169, 148-149. doi: 10.1016/0002-9378(93)90151-8

Huang, S. J., Chen, C. P., Schatz, F., Rahman, M., Abrahams, V. M., and Lockwood, C. J. (2008). Pre-eclampsia is associated with dendritic cell recruitment into the uterine decidua. J. Pathol. 214, 328-336. doi: 10.1002/path.2257

Hubel, C. A. (1999). Oxidative stress in the pathogenesis of preeclampsia. Proc. Soc. Exp. Biol. Med. 222, 222-235. doi: 10.1046/j.1525-1373.1999.d01-139.x

Hughes, R. E. (1964). Reduction of dehydroasorbic acid by animal tissues. Nature 203, 1068-1069. doi: 10.1038/2031068a0

Izquierdo Alvarez, S., Castanon, S. G., Ruata, M. L., Aragues, E. F., Terraz, P. B., Irazabal, Y. G., et al. (2007). Updating of normal levels of copper, zinc and selenium in serum of pregnant women. J. Trace Elem. Med. Biol. 21, 49-52. doi: 10.1016/j.jtemb.2007.09.023

Jauniaux, E., Watson, A. L., Hempstock, J., Bao, Y. P., Skepper, J. N., and Burton, G. J. (2000). Onset of maternal arterial blood flow and placental oxidative stress. A possible factor in human early pregnancy failure. Am. J. Pathol. 157, 2111-2122. doi: 10.1016/S0002-9440(10)64849-3

Jones, E. A., Wright, J. M., Rice, G., Buckley, B. T., Magsumbol, M. S., Barr, D. B., et al. (2010). Metal exposures in an inner-city neonatal population. Environ. Int. 36, 649-654. doi: 10.1016/j.envint.2010.04.007

Karumanchi, S. A., and Levine, R. J. (2010). How does smoking reduce the risk of preeclampsia? Hypertension 55, 1100-1101. doi: 10.1161/HYPERTENSIONAHA.109.148973

Karumanchi, S. A., and Lindheimer, M. D. (2008). Preeclampsia pathogenesis: "triple a rating"-autoantibodies and antiangiogenic factors. Hypertension 51, 991-992. doi: 10.1161/HYPERTENSIONAHA.107.100735

Kassie, G. M., Negussie, D., and Ahmed, J. H. (2014). Maternal outcomes of magnesium sulphate and diazepam use in women with severe pre-eclampsia and eclampsia in Ethiopia. Pharm. Pract. (Granada) 12:400. doi: 10.4321/S188636552014000200006

Kendall, R. L., and Thomas, K. A. (1993). Inhibition of vascular endothelial cell growth factor activity by an endogenously encoded soluble receptor. Proc. Natl. Acad. Sci. U.S.A. 90, 10705-10709. doi: 10.1073/pnas.90.22. 10705

Kendall, R. L., Wang, G., and Thomas, K. A. (1996). Identification of a natural soluble form of the vascular endothelial growth factor receptor, FLT-1, and its heterodimerization with KDR. Biochem. Biophys. Res. Commun. 226, 324-328. doi: 10.1006/bbrc.1996.1355

Kharitonova, M., Iezhitsa, I., Zheltova, A., Ozerov, A., Spasov, A., and Skalny, A. (2015). Comparative angioprotective effects of magnesium compounds. J. Trace Elem. Med. Biol. 29, 227-234. doi: 10.1016/j.jtemb.2014.06.026

Kikuchi, G., Yoshida, T., and Noguchi, M. (2005). Heme oxygenase and heme degradation. Biochem. Biophys. Res. Commun. 338, 558-567. doi: 10.1016/j.bbrc.2005.08.020

Kim-Shapiro, D. B., Schechter, A. N., and Gladwin, M. T. (2006). Unraveling the reactions of nitric oxide, nitrite, and hemoglobin in physiology and therapeutics. Arterioscler. Thromb. Vasc. Biol. 26, 697-705. doi: 10.1161/01.ATV.0000204350.44226.9a

Knight, M., Redman, C. W., Linton, E. A., and Sargent, I. L. (1998). Shedding of syncytiotrophoblast microvilli into the maternal circulation in pre-eclamptic pregnancies. Br. J. Obstet. Gynaecol. 105, 632-640. doi: 10.1111/j.14710528.1998.tb10178.x

Kristiansen, M., Graversen, J. H., Jacobsen, C., Sonne, O., Hoffman, H. J., Law, S. K., et al. (2001). Identification of the haemoglobin scavenger receptor. Nature 409, 198-201. doi: 10.1038/35051594

Kumar, S., and Bandyopadhyay, U. (2005). Free heme toxicity and its detoxification systems in human. Toxicol. Lett. 157, 175-188. doi: 10.1016/j.toxlet.2005. 03.004

Kumru, S., Aydin, S., Simsek, M., Sahin, K., Yaman, M., and Ay, G. (2003). Comparison of serum copper, zinc, calcium, and magnesium levels in preeclamptic and healthy pregnant women. Biol. Trace Elem. Res. 94, 105-112. doi: 10.1385/BTER:94:2:105

Lafayette, R. A., Druzin, M., Sibley, R., Derby, G., Malik, T., Huie, P., et al. (1998). Nature of glomerular dysfunction in pre-eclampsia. Kidney Int. 54, 1240-1249. doi: 10.1046/j.1523-1755.1998.00097.x

Lang, F., Lang, E., and Foller, M. (2012). Physiology and pathophysiology of eryptosis. Transfus. Med. Hemother. 39, 308-314. doi: 10.1159/000342534

Lavrovsky, Y., Schwartzman, M. L., Levere, R. D., Kappas, A., and Abraham, N. G. (1994). Identification of binding sites for transcription factors NF-kappa B and AP-2 in the promoter region of the human heme oxygenase 1 gene. Proc. Natl. Acad. Sci. U.S.A. 91, 5987-5991. doi: 10.1073/pnas.91.13.5987

Lee, P. C., Roberts, J. M., Catov, J. M., Talbott, E. O., and Ritz, B. (2013). First trimester exposure to ambient air pollution, pregnancy complications and adverse birth outcomes in Allegheny County, PA. Matern. Child Health J. 17, 545-555. doi: 10.1007/s10995-012-1028-5

Levine, R. J., Lam, C., Qian, C., Yu, K. F., Maynard, S. E., Sachs, B. P., et al. (2006). Soluble endoglin and other circulating antiangiogenic factors in preeclampsia. N. Engl. J. Med. 355, 992-1005. doi: 10.1056/NEJMoa055352

Lockwood, C. J., Matta, P., Krikun, G., Koopman, L. A., Masch, R., Toti, P., et al. (2006). Regulation of monocyte chemoattractant protein-1 expression by tumor necrosis factor-alpha and interleukin-lbeta in first trimester human decidual cells: implications for preeclampsia. Am. J. Pathol. 168, 445-452. doi: 10.2353/ajpath.2006.050082

Lowe, D. T. (2000). Nitric oxide dysfunction in the pathophysiology of preeclampsia. Nitric Oxide 4, 441-458. doi: 10.1006/niox.2000.0296

Lundberg, J. O., Carlstrom, M., Larsen, F. J., and Weitzberg, E. (2011). Roles of dietary inorganic nitrate in cardiovascular health and disease. Cardiovasc. Res. 89, 525-532. doi: 10.1093/cvr/cvq325

Lundberg, J. O., Weitzberg, E., and Gladwin, M. T. (2008). The nitrate-nitritenitric oxide pathway in physiology and therapeutics. Nat. Rev. Drug Discov. 7, 156-167. doi: 10.1038/nrd2466

Mackay, A. P., Berg, C. J., and Atrash, H. K. (2001). Pregnancy-related mortality from preeclampsia and eclampsia. Obstet. Gynecol. 97, 533-538. doi: 10.1016/S0029-7844(00)01223-0

Madamanchi, N. R., Vendrov, A., and Runge, M. S. (2005). Oxidative stress and vascular disease. Arterioscler. Thromb. Vasc. Biol. 25, 29-38. doi: 10.1161/01.ATV.0000150649.39934.13

Malmqvist, E., Jakobsson, K., Tinnerberg, H., Rignell-Hydbom, A., and Rylander, L. (2013). Gestational diabetes and preeclampsia in association with air pollution at levels below current air quality guidelines. Environ. Health Perspect. 121, 488-493. doi: 10.1289/ehp.1205736

Markus, T., Hansson, S., Amer-Wahlin, I., Hellstrom-Westas, L., Saugstad, O. D. and Ley, D. (2007). Cerebral inflammatory response after fetal asphyxia and hyperoxic resuscitation in newborn sheep. Pediatr. Res. 62, 71-77. doi: 10.1203/PDR.0b013e31811ead6e 
May, K., Rosenlof, L., Olsson, M. G., Centlow, M., Morgelin, M., Larsson, I., et al. (2011). Perfusion of human placenta with hemoglobin introduces preeclampsia-like injuries that are prevented by alphal-microglobulin. Placenta 32, 323-332. doi: 10.1016/j.placenta.2011.01.017

McCord, J. M., and Fridovich, I. (1988). Superoxide dismutase: the first twenty years (1968-1988). Free Radic. Biol. Med. 5, 363-369. doi: 10.1016/08915849(88)90109-8

Messerli, M., May, K., Hansson, S. R., Schneider, H., Holzgreve, W., Hahn, S., et al. (2010). Feto-maternal interactions in pregnancies: placental microparticles activate peripheral blood monocytes. Placenta 31, 106-112. doi: 10.1016/j.placenta.2009.11.011

Minakami, H., Takahashi, T., Izumi, A., and Tamada, T. (1993). Increased levels of plasma thrombomodulin in preeclampsia. Gynecol. Obstet. Invest. 36, 208-210. doi: 10.1159/000292631

Mistry, H. D., and Williams, P. J. (2011). The importance of antioxidant micronutrients in pregnancy. Oxid. Med. Cell. Longev. 2011:841749. doi: $10.1155 / 2011 / 841749$

Motterlini, R., Foresti, R., Vandegriff, K., Intaglietta, M., and Winslow, R. M. (1995). Oxidative-stress response in vascular endothelial cells exposed to acellular hemoglobin solutions. Am. J. Physiol. 269, H648-H655.

Musci, T. J., Roberts, J. M., Rodgers, G. M., and Taylor, R. N. (1988). Mitogenic activity is increased in the sera of preeclamptic women before delivery. Am. J. Obstet. Gynecol. 159, 1446-1451. doi: 10.1016/0002-9378(88)90572-8

Myatt, L. (2010). Review: reactive oxygen and nitrogen species and functional adaptation of the placenta. Placenta 31, S66-S69. doi: 10.1016/j.placenta.2009.12.021

Nordberg, J., and Arner, E. S. (2001). Reactive oxygen species, antioxidants, and the mammalian thioredoxin system. Free Radic. Biol. Med. 31, 1287-1312. doi: 10.1016/S0891-5849(01)00724-9

Nova, A., Sibai, B. M., Barton, J. R., Mercer, B. M., and Mitchell, M. D. (1991). Maternal plasma level of endothelin is increased in preeclampsia. Am. J. Obstet. Gynecol. 165, 724-727. doi: 10.1016/0002-9378(91)90317-K

Ogawa, K., Suzuki, K., Okutsu, M., Yamazaki, K., and Shinkai, S. (2008). The association of elevated reactive oxygen species levels from neutrophils with low-grade inflammation in the elderly. Immun. Ageing 5:13. doi: 10.1186/1742-4933-5-13

Olsson, M. G., Allhorn, M., Olofsson, T., and Akerstrom, B. (2007). Upregulation of alpha1-microglobulin by hemoglobin and reactive oxygen species in hepatoma and blood cell lines. Free Radic. Biol. Med. 42, 842-851. doi: 10.1016/j.freeradbiomed.2006.12.017

Olsson, M. G., Centlow, M., Rutardottir, S., Stenfors, I., Larsson, J., Hosseini-Maaf, B., et al. (2010). Increased levels of cell-free hemoglobin, oxidation markers, and the antioxidative heme scavenger alpha(1)-microglobulin in preeclampsia. Free Radic. Biol. Med. 48, 284-291. doi: 10.1016/j.freeradbiomed.2009. 10.052

Olsson, M. G., Olofsson, T., Tapper, H., and Akerstrom, B. (2008). The lipocalin alpha1-microglobulin protects erythroid K562 cells against oxidative damage induced by heme and reactive oxygen species. Free Radic. Res. 42, 725-736. doi: 10.1080/10715760802337265

Palmer, S. K., Moore, L. G., Young, D., Cregger, B., Berman, J. C., and Zamudio, S. (1999). Altered blood pressure course during normal pregnancy and increased preeclampsia at high altitude (3100 meters) in Colorado. Am. J. Obstet. Gynecol. 180, 1161-1168. doi: 10.1016/S0002-9378(99)70611-3

Pereira, K. N., Knoppka, C. K., and Da Silva, J. E. (2014). Association between uric acid and severity of pre-eclampsia. Clin. Lab. 60, 309-314.

Pompella, A., Visvikis, A., Paolicchi, A., De Tata, V., and Casini, A. F. (2003). The changing faces of glutathione, a cellular protagonist. Biochem. Pharmacol. 66, 1499-1503. doi: 10.1016/S0006-2952(03)00504-5

Poston, L., Briley, A. L., Seed, P. T., Kelly, F. J., Shennan, A. H., and Vitamins In Pre-Eclampsia Trial, C. (2006). Vitamin C and vitamin E in pregnant women at risk for pre-eclampsia (VIP trial): randomised placebo-controlled trial. Lancet 367, 1145-1154. doi: 10.1016/S0140-6736(06)68433-X

Poston, L., and Raijmakers, M. T. (2004). Trophoblast oxidative stress, antioxidants and pregnancy outcome-a review. Placenta 25, S72-S78. doi: 10.1016/j.placenta.2004.01.003

Raijmakers, M. T., Dechend, R., and Poston, L. (2004). Oxidative stress and preeclampsia: rationale for antioxidant clinical trials. Hypertension 44, 374-380. doi: 10.1161/01.HYP.0000141085.98320.01

Rayman, M. P. (2009). Selenoproteins and human health: insights from epidemiological data. Biochim. Biophys. Acta 1790, 1533-1540. doi: 10.1016/j.bbagen.2009.03.014
Redman, C. W. (2011). Hypertension in pregnancy: the NICE guidelines. Heart 97, 1967-1969. doi: 10.1136/heartjnl-2011-300949

Redman, C. W., and Sargent, I. L. (2008). Circulating microparticles in normal pregnancy and pre-eclampsia. Placenta 29, S73-S77. doi: 10.1016/j.placenta.2007.11.016

Redman, C. W., and Sargent, I. L. (2009). Placental stress and preeclampsia: a revised view. Placenta 30(Suppl. A), S38-S42. doi: 10.1016/j.placenta.2008.11.021

Redman, C. W., and Sargent, I. L. (2010). Immunology of pre-eclampsia. Am. J. Reprod. Immunol. 63, 534-543. doi: 10.1111/j.1600-0897.2010.00831.x

Roberts, J. M., and Escudero, C. (2012). The placenta in preeclampsia. Pregnancy Hypertens. 2, 72-83. doi: 10.1016/j.preghy.2012.01.001

Roberts, J. M., and Hubel, C. A. (2009). The two stage model of preeclampsia: variations on the theme. Placenta, 30 Suppl. A, S32-S37. doi: 10.1016/j.placenta.2008.11.009

Roberts, J. M., Taylor, R. N., Musci, T. J., Rodgers, G. M., Hubel, C. A., and McLaughlin, M. K. (1989). Preeclampsia: an endothelial cell disorder. Am. J. Obstet. Gynecol. 161, 1200-1204. doi: 10.1016/0002-9378(89)90665-0

Rodgers, G. M., Taylor, R. N., and Roberts, J. M. (1988). Preeclampsia is associated with a serum factor cytotoxic to human endothelial cells. Am. J. Obstet. Gynecol. 159, 908-914. doi: 10.1016/S0002-9378(88)80169-8

Rodriguez, M., Moreno, J., and Hasbun, J. (2012). RAS in pregnancy and preeclampsia and eclampsia. Int. J. Hypertens. 2012:739274. doi: $10.1155 / 2012 / 739274$

Rudov, A., Balduini, W., Carloni, S., Perrone, S., Buonocore, G., and Albertini, M. C. (2014). Involvement of miRNAs in placental alterations mediated by oxidative stress. Oxid. Med. Cell. Longev. 2014:103068. doi: 10.1155/2014/103068

Rumbold, A., Duley, L., Crowther, C. A., and Haslam, R. R. (2008). Antioxidants for preventing pre-eclampsia. Cochrane Database Syst. Rev. CD004227. doi: 10.1002/14651858.CD004227.pub3

Rumbold, A. R., Crowther, C. A., Haslam, R. R., Dekker, G. A., Robinson, J. S., and Group, A. S. (2006). Vitamins C and E and the risks of preeclampsia and perinatal complications. N. Engl. J. Med., 354, 1796-1806. doi: 10.1056/NEJMoa054186

Rumiris, D., Purwosunu, Y., Wibowo, N., Farina, A., and Sekizawa, A. (2006). Lower rate of preeclampsia after antioxidant supplementation in pregnant women with low antioxidant status. Hypertens. Pregnancy 25, 241-253. doi: 10.1080/10641950600913016

Rush, G. F., Gorski, J. R., Ripple, M. G., Sowinski, J., Bugelski, P., and Hewitt, W. R. (1985). Organic hydroperoxide-induced lipid peroxidation and cell death in isolated hepatocytes. Toxicol. Appl. Pharmacol. 78, 473-483. doi: 10.1016/0041$008 X(85) 90255-8$

Rusterholz, C., Hahn, S., and Holzgreve, W. (2007). Role of placentally produced inflammatory and regulatory cytokines in pregnancy and the etiology of preeclampsia. Semin. Immunopathol. 29, 151-162. doi: 10.1007/s00281-0070071-6

Ryter, S. W., Alam, J., and Choi, A. M. (2006). Heme oxygenase-1/carbon monoxide: from basic science to therapeutic applications. Physiol. Rev. 86, 583-650. doi: 10.1152/physrev.00011.2005

Salafia, C. M., Pezzullo, J. C., Lopez-Zeno, J. A., Simmens, S., Minior, V. K., and Vintzileos, A. M. (1995). Placental pathologic features of preterm preeclampsia. Am. J. Obstet. Gynecol. 173, 1097-1105. doi: 10.1016/0002-9378(95)91333-5

Sautin, Y. Y., and Johnson, R. J. (2008). Uric acid: the oxidant-antioxidant paradox. Nucleosides Nucleotides Nucleic Acids 27, 608-619. doi: $10.1080 / 15257770802138558$

Schneider, H., and Huch, A. (1985). Dual in vitro perfusion of an isolated lobe of human placenta: method and instrumentation. Contrib. Gynecol. Obstet. 13, 40-47.

Scholz, R. W., Graham, K. S., Gumpricht, E., and Reddy, C. C. (1989). Mechanism of interaction of vitamin $\mathrm{E}$ and glutathione in the protection against membrane lipid peroxidation. Ann. N.Y. Acad. Sci. 570, 514-517. doi: 10.1111/j.17496632.1989.tb14973.x

Schroeder, B. M., American College Of, O., and Gynecologists (2002). ACOG practice bulletin on diagnosing and managing preeclampsia and eclampsia. American College of Obstetricians and Gynecologists. Am. Fam. Physician 66, 330-331.

Sela, S., Itin, A., Natanson-Yaron, S., Greenfield, C., Goldman-Wohl, D., Yagel, S., et al. (2008). A novel human-specific soluble vascular endothelial growth factor receptor 1: cell-type-specific splicing and implications to vascular endothelial 
growth factor homeostasis and preeclampsia. Circ. Res. 102, 1566-1574. doi: 10.1161/CIRCRESAHA.108.171504

Serdar, Z., Gur, E., and Develioglu, O. (2006). Serum iron and copper status and oxidative stress in severe and mild preeclampsia. Cell Biochem. Funct. 24, 209-215. doi: 10.1002/cbf.1235

Shmueli, A., Meiri, H., and Gonen, R. (2012). Economic assessment of screening for pre-eclampsia. Prenat. Diagn. 32, 29-38. doi: 10.1002/pd.2871

Sibai, B. M. (2005). Magnesium sulfate prophylaxis in preeclampsia: evidence from randomized trials. Clin. Obstet. Gynecol. 48, 478-488. doi: 10.1097/01.grf.0000160314.59736.d2

Smarason, A. K., Sargent, I. L., Starkey, P. M., and Redman, C. W. (1993). The effect of placental syncytiotrophoblast microvillous membranes from normal and pre-eclamptic women on the growth of endothelial cells in vitro. $\mathrm{Br} . J$. Obstet. Gynaecol. 100, 943-949. doi: 10.1111/j.1471-0528.1993.tb15114.x

Sontia, B., and Touyz, R. M. (2007). Role of magnesium in hypertension. Arch. Biochem. Biophys. 458, 33-39. doi: 10.1016/j.abb.2006.05.005

Souza, A. S., Amorim, M. M., Coutinho, I. C., Lima, M. M., Noronha Neto, C., and Figueroa, J. N. (2010). Effect of the loading dose of magnesium sulfate (MgSO4) on the parameters of Doppler flow velocity in the uterine, umbilical and middle cerebral arteries in severe preeclampsia. Hypertens. Pregnancy 29, 123-134. doi: $10.3109 / 10641950902875772$

Spinnato, J. A. II (2006). New therapies in the prevention of preeclampsia. Curr. Opin. Obstet. Gynecol. 18, 601-604. doi: 10.1097/01.gco.0000247393.86968.e6

Stillman, I. E., and Karumanchi, S. A. (2007). The glomerular injury of preeclampsia. J. Am. Soc. Nephrol. 18, 2281-2284. doi: 10.1681/ASN.2007020255

Strevens, H., Wide-Swensson, D., Hansen, A., Horn, T., Ingemarsson, I., Larsen, S., et al. (2003). Glomerular endotheliosis in normal pregnancy and pre-eclampsia. BJOG 110, 831-836. doi: 10.1111/j.1471-0528.2003.02162.x

Sverrisson, K., Axelsson, J., Rippe, A., Gram, M., Akerstrom, B., Hansson, S. R., et al. (2014). Extracellular fetal hemoglobin induces increases in glomerular permeability: inhibition with alpha1-microglobulin and tempol. Am. J. Physiol. Renal Physiol. 306, F442-F448. doi: 10.1152/ajprenal.00502.2013

Tannetta, D. S., Dragovic, R. A., Gardiner, C., Redman, C. W., and Sargent, I. L. (2013). Characterisation of syncytiotrophoblast vesicles in normal pregnancy and pre-eclampsia: expression of Flt-1 and endoglin. PLoS ONE 8:e56754. doi: 10.1371/journal.pone.0056754

Taylor, R. N., Crombleholme, W. R., Friedman, S. A., Jones, L. A., Casal, D. C., and Roberts, J. M. (1991). High plasma cellular fibronectin levels correlate with biochemical and clinical features of preeclampsia but cannot be attributed to hypertension alone. Am. J. Obstet. Gynecol. 165, 895-901. doi: 10.1016/00029378(91)90435-T

Terzano, C., Di Stefano, F., Conti, V., Graziani, E., and Petroianni, A. (2010). Air pollution ultrafine particles: toxicity beyond the lung. Eur. Rev. Med. Pharmacol. Sci. 14, 809-821.

Thachil, J., and Toh, C. H. (2009). Disseminated intravascular coagulation in obstetric disorders and its acute haematological management. Blood Rev. 23, 167-176. doi: 10.1016/j.blre.2009.04.002

Thomas, C. P., Andrews, J. I., Raikwar, N. S., Kelley, E. A., Herse, F., Dechend, R., et al. (2009). A recently evolved novel trophoblast-enriched secreted form of fms-like tyrosine kinase-1 variant is up-regulated in hypoxia and preeclampsia. J. Clin. Endocrinol. Metab. 94, 2524-2530. doi: 10.1210/jc.2009-0017

Thorp, J. M. Jr., White, G. C. II., Moake, J. L., and Bowes, W. A. Jr. (1990). von Willebrand factor multimeric levels and patterns in patients with severe preeclampsia. Obstet. Gynecol. 75, 163-167.

Tjoa, M. L., Cindrova-Davies, T., Spasic-Boskovic, O., Bianchi, D. W., and Burton, G. J. (2006). Trophoblastic oxidative stress and the release of cell-free fetoplacental DNA. Am. J. Pathol. 169, 400-404. doi: 10.2353/ajpath,.2006.060161

Valko, M., Leibfritz, D., Moncol, J., Cronin, M. T., Mazur, M., and Telser, J. (2007). Free radicals and antioxidants in normal physiological functions and human disease. Int. J. Biochem. Cell Biol. 39, 44-84. doi: 10.1016/j.biocel.2006.07.001

Vanderlelie, J., Venardos, K., Clifton, V. L., Gude, N. M., Clarke, F. M., and Perkins, A. V. (2005). Increased biological oxidation and reduced antioxidant enzyme activity in pre-eclamptic placentae. Placenta 26, 53-58. doi: 10.1016/j.placenta.2004.04.002

Vigeh, M., Yokoyama, K., Ramezanzadeh, F., Dahaghin, M., Fakhriazad, E., Seyedaghamiri, Z., et al. (2008). Blood manganese concentrations and intrauterine growth restriction. Reprod. Toxicol. 25, 219-223. doi: 10.1016/j.reprotox.2007.11.011

Villar, J., Purwar, M., Merialdi, M., Zavaleta, N., Thi Nhu Ngoc, N., Anthony, J., et al. (2009). World Health Organisation multicentre randomised trial of supplementation with vitamins $\mathrm{C}$ and $\mathrm{E}$ among pregnant women at high risk for pre-eclampsia in populations of low nutritional status from developing countries. BJOG 116, 780-788. doi: 10.1111/j.1471-0528.2009.02158.x

Wagner, S. J., Craici, I. M., Grande, J. P., and Garovic, V. D. (2012). From placenta to podocyte: vascular and podocyte pathophysiology in preeclampsia. Clin. Nephrol. 78, 241-249. doi: 10.5414/CN107321

Walsh, S. W. (1998). Maternal-placental interactions of oxidative stress and antioxidants in preeclampsia. Semin. Reprod. Endocrinol. 16, 93-104. doi: 10.1055/s2007-1016256

Walshe, T. E., Saint-Geniez, M., Maharaj, A. S., Sekiyama, E., Maldonado, A. E., and D'Amore, P. A. (2009). TGF-beta is required for vascular barrier function, endothelial survival and homeostasis of the adult microvasculature. PLoS ONE 4:e5149. doi: 10.1371/journal.pone.0005149

Wang, A., Rana, S., and Karumanchi, S. A. (2009). Preeclampsia: the role of angiogenic factors in its pathogenesis. Physiology (Bethesda) 24, 147-158. doi: 10.1152/physiol.00043.2008

Wang, Y., and Walsh, S. W. (1996). Antioxidant activities and mRNA expression of superoxide dismutase, catalase, and glutathione peroxidase in normal and preeclamptic placentas. J. Soc. Gynecol. Investig. 3, 179-184. doi: 10.1016/10715576(96)00015-9

Webb, A. J., Patel, N., Loukogeorgakis, S., Okorie, M., Aboud, Z., Misra, S., et al. (2008). Acute blood pressure lowering, vasoprotective, and antiplatelet properties of dietary nitrate via bioconversion to nitrite. Hypertension 51, 784-790. doi: 10.1161/HYPERTENSIONAHA.107.103523

Wester-Rosenlof, L., Casslen, V., Axelsson, J., Edstrom-Hagerwall, A., Gram, M., Holmqvist, M., et al. (2014). A1M/alpha1-microglobulin protects from hemeinduced placental and renal damage in a pregnant sheep model of preeclampsia. PLoS ONE 9:e86353. doi: 10.1371/journal.pone.0086353

Wimalasundera, R. C., Larbalestier, N., Smith, J. H., De Ruiter, A., McG Thom, S. A., Hughes, A. D., et al. (2002). Pre-eclampsia, antiretroviral therapy, and immune reconstitution. Lancet 360, 1152-1154. doi: 10.1016/S01406736(02)11195-0

Wolf, M., Kettyle, E., Sandler, L., Ecker, J. L., Roberts, J., and Thadhani, R. (2001). Obesity and preeclampsia: the potential role of inflammation. Obstet. Gynecol. 98, 757-762. doi: 10.1016/S0029-7844(01)01551-4

Wu, J., Ren, C., Delfino, R. J., Chung, J., Wilhelm, M., and Ritz, B. (2009). Association between local traffic-generated air pollution and preeclampsia and preterm delivery in the south coast air basin of California. Environ. Health Perspect. 117, 1773-1779. doi: 10.1289/ehp.0800334

Wu, J., Wilhelm, M., Chung, J., and Ritz, B. (2011). Comparing exposure assessment methods for traffic-related air pollution in an adverse pregnancy outcome study. Environ. Res. 111, 685-692. doi: 10.1016/j.envres.2011. 03.008

Yung, H. W., Atkinson, D., Campion-Smith, T., Olovsson, M., Charnock-Jones, D. S., and Burton, G. J. (2014). Differential activation of placental unfolded protein response pathways implies heterogeneity in causation of early- and late-onset pre-eclampsia. J. Pathol. 234, 262-276. doi: 10.1002/path.4394

Zavalza-Gomez, A. B. (2011). Obesity and oxidative stress: a direct link to preeclampsia? Arch. Gynecol. Obstet. 283, 415-422. doi: 10.1007/s00404-0101753-1

Conflict of Interest Statement: Stefan R. Hansson holds patents for the diagnosis and treatment of preeclampsia. Stefan R. Hansson is co-founder of the companies Preelumina Diagnostics AB and A1M Pharma AB. The other authors declare that the research was conducted in the absence of any commercial or financial relationships that could be construed as a potential conflict of interest.

Received: 09 October 2014; accepted: 16 December 2014; published online: 13 January 2015.

Citation: Hansson SR, Nääv A and Erlandsson L (2015) Oxidative stress in preeclampsia and the role of free fetal hemoglobin. Front. Physiol. 5:516. doi: 10.3389/fphys. 2014.00516

This article was submitted to Oxidant Physiology, a section of the journal Frontiers in Physiology.

Copyright (C) 2015 Hansson, Nääv and Erlandsson. This is an open-access article distributed under the terms of the Creative Commons Attribution License (CC BY). The use, distribution or reproduction in other forums is permitted, provided the original author(s) or licensor are credited and that the original publication in this journal is cited, in accordance with accepted academic practice. No use, distribution or reproduction is permitted which does not comply with these terms. 